\title{
Low Wind Speed Technology Phase I: Evaluation of Design and Construction Approaches for Economical Hybrid Steel/Concrete Wind Turbine Towers
}

\section{BERGER/ABAM Engineers Inc.}

Project Description: This work addressed the economic feasibility of concrete and hybrid concrete/steel wind turbine towers. The wind turbine/tower sizes that formed a basis for comparing concepts are:

-1.5-MW turbine on a 100-m tower

-3.6-MW turbine on a 100-m tower

- 5.0-MW turbine on a 100-m tower.

The design concepts included hybrid steel/concrete towers with 47-49-m concrete base tower sections and 51-53-m steel top tower sections and all-concrete towers $100 \mathrm{~m}$ tall.

The study considered several construction approaches and developed prices for the concepts. A segmental precast concrete approach was developed in some detail for the 1.5-MW tower and was scaled for the 3.6- and 5.0-MW turbines. Additionally, researchers considered slip- and jump-forming construction methods to evaluate cast-in-place (CIP) concrete construction.

A method for reducing the height of the heavy lifts for installing the turbine and rotors atop the tower was developed in some detail. The results indicate that the costs for the 1.5-MW/100-m tower- the hybrid steel/concrete, the CIP concrete, and the tubular steel towers - are all within 33\% of each other. The CIP concrete approach modifies conventional industrial chimney construction and is estimated to be the lowest cost solution. The cost savings associated with nacelle semi self-erection at $50 \mathrm{~m}$ versus $100 \mathrm{~m}$ do not provide a strong cost advantage over the hybrid steel/ concrete. For the $3.6-\mathrm{MW} / 100-\mathrm{m}$ tower, the CIP concrete concept is $68 \%$ of the estimated cost of the tubular steel concept. For the 5.0-MW/100-m tower, the CIP concrete concept is $63 \%$ of the estimated cost of the tubular steel tower concept.

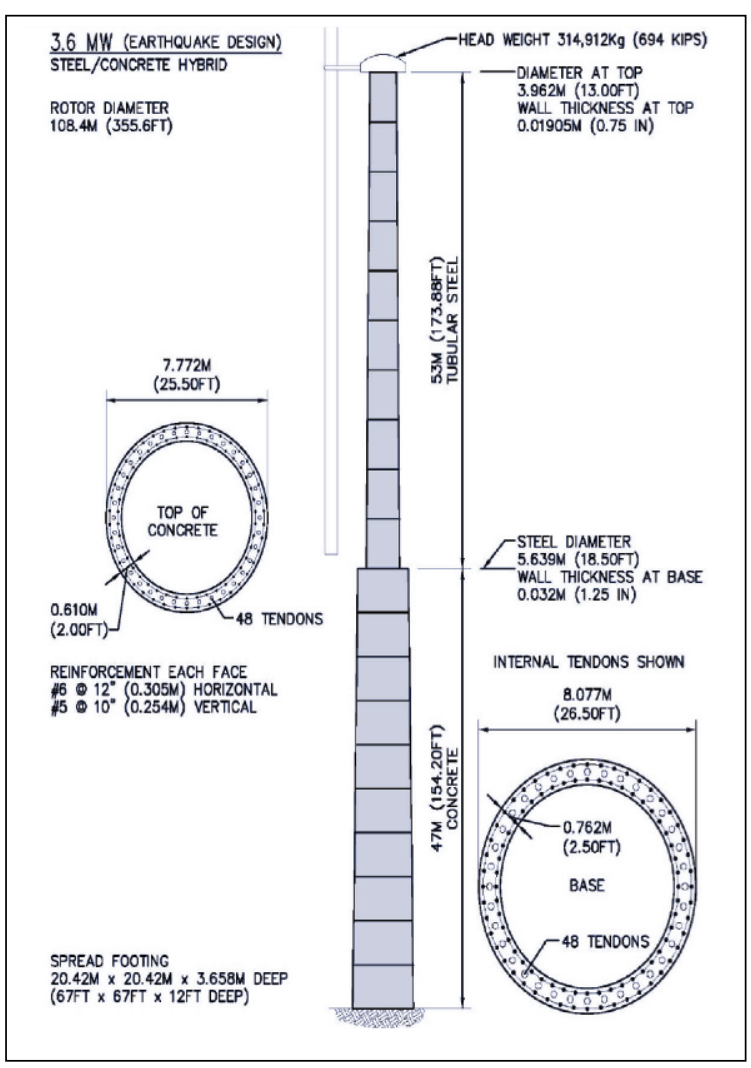

Schematic for a hybrid steel/concrete wind turbine tower.

\section{Project Type: \\ Project Budget: \\ Industry Cost Share: \\ DOE Cost Share: \\ Conceptual Design Study \\ $\$ 209,947$ \\ $\$ 0$ \\ $\$ 209,947$}

Planned Project Duration: June 2002-July 2004

\section{Current Status:}

Project Complete-Final Report, LWST Phase I Project Conceptual Design Study: Evaluation of Design and Construction Approaches for Economical Hybrid Steel/Concrete Wind Turbine Towers www.nrel.gov/docs/fy05osti/36777.pdf

\section{Contacts:}

NREL/Sandia:

David Simms, NREL

1617 Cole Blvd.

Golden, Colorado 80401

303-384-6942

david_simms@nrel.gov

\author{
Berger/Abam: \\ Michael W. LaNier, BERGER/ABAM Engineers Inc. \\ 33301 Ninth Ave. S, Suite 300 \\ Federal Way, Washington 98003-2600 \\ 206-431-2300 \\ lanier@abam.com
}

\begin{abstract}
A Strong Portfolio for a Strong America • Energy efficiency and clean, renewable energy will mean a stronger economy, a cleaner environment, and greater energy independence for America. Working with a wide array of state, community, industry, and university partners, the U.S. Department of Energy's Office of Energy Efficiency and Renewable Energy invests in a diverse portfolio of energy technologies.
\end{abstract}

For more information contact EERE Information Center • 1-877-EERE-INF (1-877-337-3463) • www.eere.energy.gov

Produced for the U.S. Department of Energy by the National Renewable Energy Laboratory, a DOE national laboratory 